(2)

\title{
Art in the Streets of a Shattered City
}

\section{Anne Kristiina Kurjenoja and Emilia Ismael}

\begin{abstract}
Global economic trends have triggered processes of cultural re-territorialization in Latin American cities by fostering the desire to become "global cities." These processes have increased social inequality through the effects of economic polarization and the gentrification of urban areas. Manifestations of dissent are frequently expressed and negotiated through contesting non-institutional urban artistic practices, among them street art and "art in the streets." Urban groups have historically used cultural practices as politics of dissent. In the context of global cities, though, these cultural practices are threatened by public policies that favour cultural industries and attempt to manage them as goods and services for the overall production of added value to the city. The result is a culturally shattered geography of accented social marginality. This paper analyzes the regulation and domestication of art in the streets of Puebla, Mexico, in order to consider the impact of global economic trends on local urban cultures, cities, and citizens.
\end{abstract}

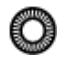

\section{Introduction: Urban Space and Alterity}

The economic dynamics of globalization have increased social inequality in Latin America through the economic polarization of its territories, gentrification, and increased social fragmentation (Sassen 7-8). In the Mexican city of Puebla, located in the central plateau of the country, cultural re-territorialization has contributed to a shattered cultural geography of marginality, one which frequently displays the non-institutional creative and artistic practices of local urban tribes that stand in tension with the city's official touristic, global economy-oriented cultural image. Puebla, founded in 1531, was the first colonial city in New Spain, constructed on virgin land without previous urbanization. The territorial segmentation of the city's urban population was clear from the beginning: the colonizers were separated from the indigenous natives by a river only connected by bridges for the purpose of workforce supply. This physical and social separation still exists, though not so much in racial terms as in socio-economic and cultural relations. Today, this alterity has, in some places, turned into a transformative and contesting force through cultural manifestations of street art. These expressions of territorial re-appropriation sometimes stand in opposition to the 
political forces trying to "domesticate" every corner of the urban scape in order to insert the city into productive global models and networks (Foster, "Recodificaciones" 3). ${ }^{1}$ Sometimes, however, domesticating economic forces in fact neutralize cultural re-territorializations.

In the following paper, we will discuss two such cases. The first is the project Ciudad Mural [Mural City], conducted by an activists' collective since the year 2010 and carried out in four stages in a marginal neighborhood in the historic district of Puebla. This project grew out of collective participation between activists and neighbours to become an emblem of the cultural vibrancy of a Creative City's tourist agenda. The second case is that of the Programa de Artistas Urbanos (PAU) [Program of Urban Artists], implemented in 2017 by Puebla's city council as regulation on public spaces that restricts access but to a few areas in the city and only to those artists authorized through the program. The city thus engages in a continuous cultural re-territorialization to contest the struggle against the global political imperative often enacted through cultural-urban public policies. Several metropolitan areas of Latin America, such as Puebla, have recently been under the influence of the global creative economy, triggering public policies that have actively sought inclusion in global urban networks and systems of urban certifications, such as UNESCO's Creative Cities Network (CCN) and the Smart City certification by the International Standards Organization (ISO). In order to reach these goals, the urban administration has had to reconfigure the idea of the contemporary Latin American city according to a framework of economic development introduced by the Inter-American Development Bank (IDB), where creative economies and industries are the motor for future Latin American prosperity. Such policies try to incorporate and domesticate urban creative practices into the functions of cultural resources, first, to cultivate an

\footnotetext{
1 "Domestication" here is understood, as Hal Foster points out, as the notion of inoculation, in which the Other is absorbed by the Same to make it innocuous ("Recodificaciones" 6). Thus, political and economic forms converge in the form of a commodity, a sign made commercially productive as merchandise. This way, the Other is controlled in its recognition, in which cultural difference is fabricated to establish social control. Appropriation is the master operation through which the culturally different is absorbed by the dominant culture and converted to a sign.
} 
attractive cosmopolitan urban image with an exotic touch of local identity and, second, to stimulate flows of capital and speculation practices.

\section{Global Cities, Local Citizens}

The concept of global cities has rendered human creativity a useful resource for the economic growth of contemporary societies. Thus, all kinds of cultural practices are frequently absorbed by industries in a wide-ranging production of cultural goods and services. For creative industries, the material urban environment is crucial because of its fundamental capacity to gather social, cultural, and ethnic diversity, so spaces like streets or urban squares become sources of a new civility in terms of a creative economy (Florida 147-53).

For cities in pursuit of global status, the image of a vigorous cultural life is politically and economically imperative as a stimulus for innovation, the attraction of human capital, and, in most cases, the foundation of a prosperous tourist industry that will foster, promote, and capitalize on local cultural particularities. Institutional, economic, and political actors supporting these models affect a city's cultural, social, and productive practices by prioritizing and spurring the transformation of economically strategic urban assets while others are left unattended. Urban-cultural public policies in the global city are too often unable to visualize the city as an integral and complex whole, bedazzled by the eclecticism of a fashionable lifestyle culture, rather than seeking sustainable, broad, and transversal social benefits. The result is a city of fiction, instead of a city of function, in which the urban image has substituted the urban substance (Harvey, Spaces 362).

Furthermore, in the context of a global approach to city development, traditional cultural institutions are displaced by urban experiences offered by the local culture - that is, not in museums or theatres but in open public spaces, constructing an ecosystem in which "the spheres of innovation (technological creativity), business (economic creativity), and culture (artistic and cultural creativity)" are drawn together "in more intimate and more powerful 
combinations than ever" (Florida 169). Culture in general is then subordinated to the global economy as an investment product. Accordingly, the political meaning of art and culture is displaced to its strategic location in the urban context as an efficient producer of a carefully designed global city imaginary. The political function is drawn into the symbolic meaning of art and culture as an icon of a creative and economic power, and the consumption of these geopolitical meanings transforms the modern "homo economicus" into a lifestyle-consuming "homo significans" (Foster, "Recodificaciones" 3). As a result, cultural public policies that attend to the homo significans transform the urban image through the use of public spaces and historical districts as potential machines for economic growth via tourism, entertainment, and the marketization of lifestyles. The process of urban cultural policy thus shatters the city by sequestering culture from its social ontology and leaving local citizens with limited functioning mechanisms for negotiating their "right to the city" vis-à-vis global economic pressures.

\section{Local Art in the Global City}

In the context of global cities, public cultural politics frequently transform streets, parks, and urban squares into galleries of commodification (Armstrong 4). It is also often the case that traditional institutions offer a romanticized, fetishistic discourse of local art and history. Thus, aesthetics becomes politics, and the political rationale for urban space is to expose a wide array of products from creative practices, justified by what Robert Hughes calls the "ideal of social renewal by cultural challenge" (372). In the case of the city of Puebla, the Creative City and Smart City models have been strongly promoted since 2014, when the federal commerce office, ProMéxico, published a plan called Puebla Capital de Innovación y Diseño (PueblaCID) [Puebla Capital of Innovation and Design]. This program for economic development, based on the creative economy or "Orange Economy" model, resulted in the city's accreditation as a Creative City by the CCN in 2015 and as a Smart City by the ISO in 2016. 
Creative practices and culture are now, within this framework, ordered into urban public policy to make connections between the marketization of identity and the service industry. As we will see in the following section, by incorporating specific spectacular cultural practices into the tourism industry and regulating the use of public spaces, Puebla's cultural-urban public policy has engaged in a kind of fracking - in the sense of putting pressure on the urban culture in order to extract its commercial and economic value.

The public institutions involved in locating culture in public space - in Puebla, the Instituto Municipal de Arte y Cultura de Puebla (IMACP); the city council; and the state tourism ministry (just recently renamed for tourism and culture), the Secretaría de Cultura y Turismo - intend to economically activate art in the streets by transforming it into part of the urban spectacle of a global city. While we see that street culture is domesticated into specific marketing projects or regulated (insofar as which practices are better suited for the image of the city), questions arise about which interests are defining the public space, which political and economic imaginaries of the local identity are being favoured, and whose social needs and means of expression are being emptied and neutralized into rentable visual attractions.

\section{Art in the Streets and the Neutralization of Alterity: A Shattered City}

The commodification of the local urban culture for a global tourist and lifestyle market can be observed as a process of domestication - that is, the absorption of the Other to render it innocuous or neutralize it (Foster, "Recodificaciones" 5). In this reading of street art, or "art in the streets," cultural practices are objectivized as representations of the Other, located in the position of something admirable and different, acquiring the aura of superficial authenticity and political innovation (Foster, Return 305-7). Local culture emerges as a fetish of difference absorbed only as a sign of alterity by the political hegemony. The domestication process further requires that this sign is purified of its contesting character and that new cultural values are assigned. 
The city of Puebla, as we will see in the following section, has undertaken similar processes by the enactment of touristic-cultural policies directed towards street art and art in the streets. The first of two of such examples is the absorption of Ciudad Mural - a series of murals created by a local community in collaboration with a collective of activists through a years-long project for social development into the tourist circuit of the city's historic downtown area. The core values of the initial project were directed towards empowering the community to define and portray, in a highly visible way, who they were and who they wanted to be. While the murals still stand, the social development component has long been abandoned for the economic pledge of tourism. The second and most recent example of these kinds of policies is a regulatory program for urban artists, passed by the city council and enacted by the municipal arts and culture office, which aims to clear the streets of informal labour, control cultural tastes for tourism, and regulate the use of public spaces.

The encounter between urban culture and public policies in the city is thus mapped in positivistic terms through forms of political affinities and morphological coincidences, not in terms of social development. This model of public policy thus tends to separate the contents of the local urban culture from their social context, choosing only the signs most convenient to economic policies. The domestication pursued by hegemonic economic and political interests enforces new meaning codifications and circulation trajectories that ultimately neutralize the potential political dissent of artistic and cultural practices in the street.

In "The 'Primitive' Unconscious of Modern Art," Hal Foster explains how hegemonic interests transfigure contesting local cultures into a myth of difference in order to appropriate them into one of its own signs; this absorption is an act of power. The author refers to the "decentering of the same" (67), where the shattering of the modern subject - by neutralizing all signs of alterity - was first a vehicle for the universalization of the knowledge-power modern project and is 
now a means of domesticating the Other into the contemporary globalized cultural economy. The globalized cultural economy thus "has begun to recycle its own historical episodes as styles together with its appropriated images of exotica (of domesticated otherness)" (69).

\section{Ciudad Mural in Xanenetla, Puebla}

From 2010 to 2012, a group of artists and activists called Colectivo Tomate, in collaboration with the local population of Xanenetla, one of the oldest popular neighborhoods in Puebla, initiated a project of urban muralism, aimed at renovating the facades of a total of eighty-eight houses. The idea was to cover their main facades with murals in order to dignify the district and give visibility to the community living there. The murals depict traditions, local legends, and personal experiences and anecdotes, all in response to three basic questions: (1) How did we get here? (2) Who are we? and (3) Who do we want to be? The main goal of the artwork was to rehabilitate public spaces through participative art, inspired by previous work of this kind in Brazilian favelas, where local young people used images of their dreams to cover the urban epidermis of their environment in order to empower local habitants to achieve a new social cohesion. The series of murals plays with representative ideas of the local community, seeking images that could work as icons for the district's new identity and its renovated character as the dignified home of hard-working people (Kurjenoja and Ismael 268-75).

Soon after the first phases of the project, the neighbourhood began to gain visibility through social media, drawing, for the first time, the attention of city authorities and the private sector. This resulted in financial support in order to continue subsequent stages of the project. The Mural City of Xanenetla was subsequently included in official tourist literature and incorporated into the historic district of Puebla's tour routes. The renewed position of the neighbourhood as a tourist attraction demanded urban upgrading in those public areas where tourists were to circulate. Some sidewalks and public lighting were 
restored while the rest of the district's urban necessities were left unattended, fragmenting the vicinity itself into privileged and unprivileged areas. The media attention made Xanenetla a selected place for official visits from foreign city mayors and ambassadors, as well as from UNESCO representatives, distinguishing the district as a one-of-a-kind cultural asset in Latin America and positioning the city of Puebla and the Colectivo Tomate as facilitators for this kind of project in other cities and countries.

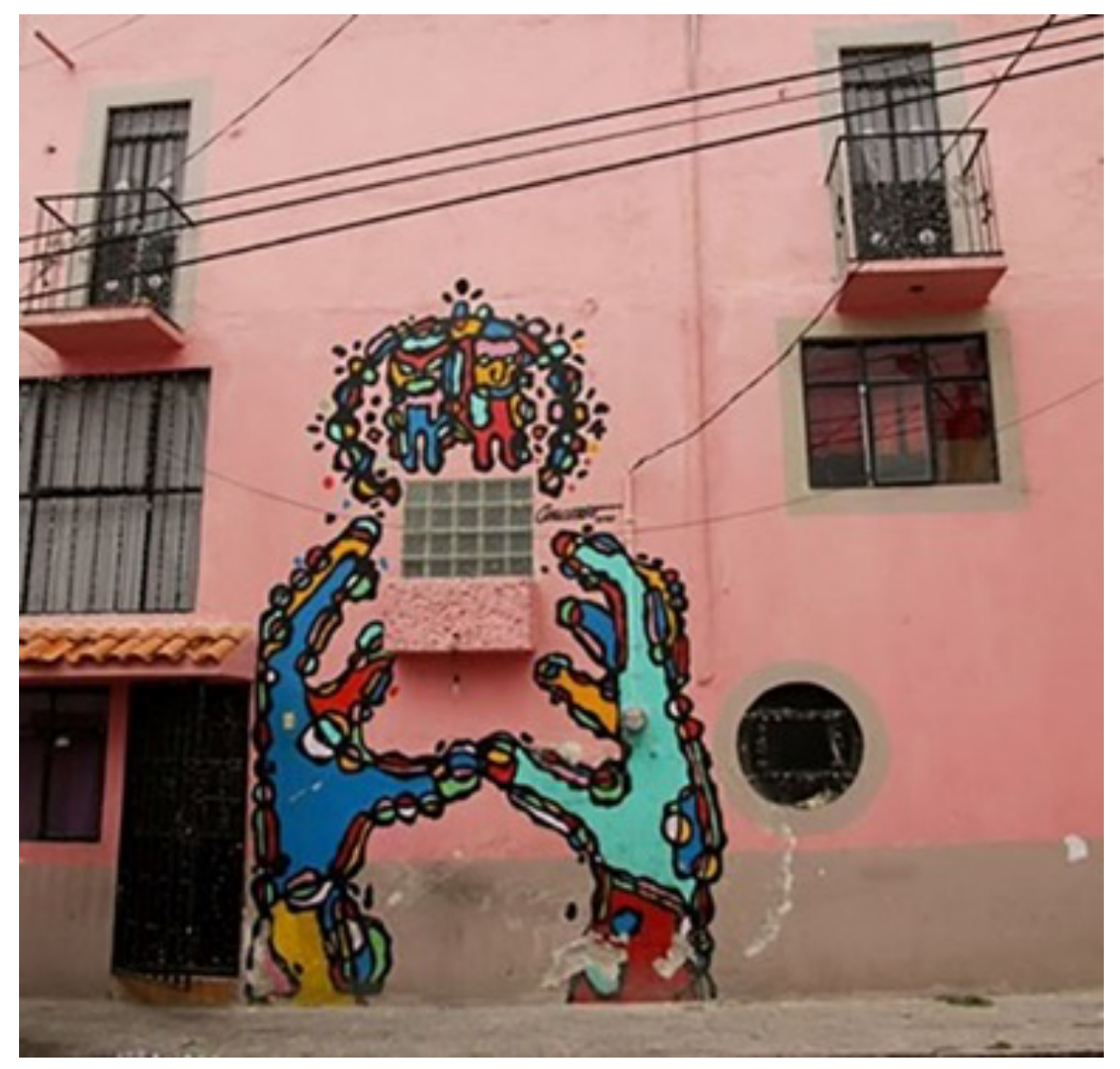

Figure 1: Part of the Puebla Ciudad Mural in Xanenetla. (Photo: Carolina Tabares, 2011.)

The short-lived urban upgrading in the district attended mainly aesthetic problems and not those related to the quality of life of the local people; what had begun as a project for the reconstruction of the local social fabric soon became oriented to its commodification. Puebla's "Plan Municipal de Desarrollo, 20112014" [Municipal Development Plan, 2011-2014] highlights that strategies related 
to tourism must be oriented to exploiting emergent opportunities, such as cultural heritage and entertainment services, in order to create products of cultural activity and entertainment for tourists, other visitors, and city inhabitants (87-88). These plans failed to address the most urgent socioeconomic problems of the district, including the preservation of its historical heritage, but the project did increase the district's potential for real estate speculation by the service industry, which can be seen in the increased number of new bars, hotels, and cafes in nearby areas.

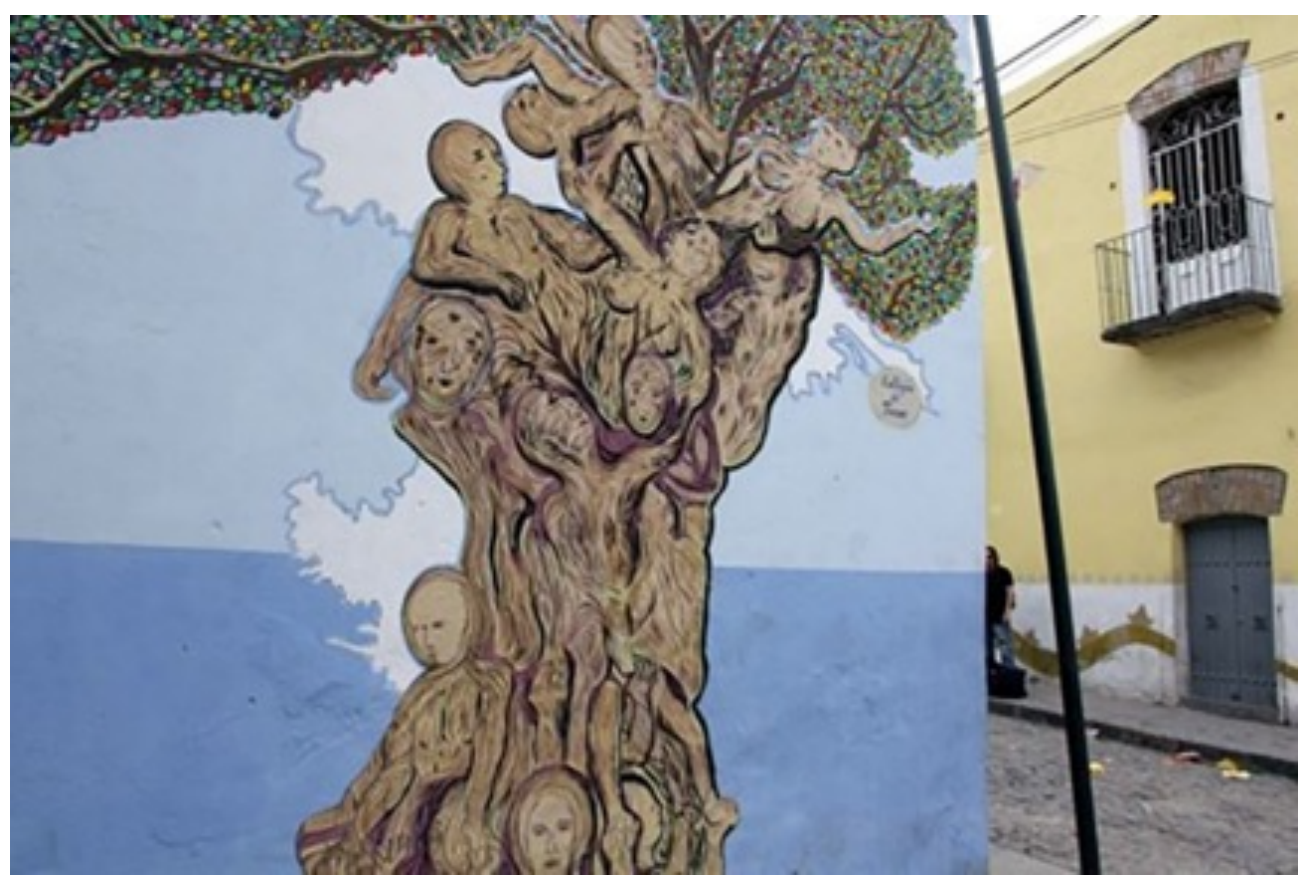

Figure 2: The Mural City of Xanenetla, Puebla. (Photo: Carolina Tabares, 2011.)

What was initially an expression of alterity through a cultural action of civil society, meant to dignify the area and re-signify it through muralism, was ultimately absorbed by global trends of economics and culture. The domestication of the murals of Xanenetla neutralized an expression of alterity by recasting the work as a purely aesthetic good, shattering a socially contestative cultural practice that attempted to address deficient living conditions. When neutralized by the dominant culture economy, cultural alterity becomes de-structured as what 
Kenneth Burke calls a "representative anecdote" (Burke 59). Such representative anecdotes generate cultural re-territorialization in the city, projecting a dynamic local culture able to lure capital and real estate services and potentialize the tourist industry (Harvey, Spaces 139).

\section{Program for Urban Artists}

When making the city, the individual is making also him- or herself. As David Harvey points out, "the question of what kind of city we want cannot be divorced from the question of what kind of people we want to be, what kinds of social relations we seek, what relations to nature we cherish, what style of life we desire, what aesthetic values we hold" (Rebel 4). The right to the city is also the right to change and reinvent the city. Reinventing a city, however, inevitably depends upon the exercise of a collective power over the processes of re-creating the public space and its image. The freedom to make and remake ourselves is related to the right to participate in the remaking of our context. Throughout history, the human being has made and remade itself through powerful social processes in which the urban space has been an important factor.

Many of these social processes are enacted and negotiated through informal art in the streets and other urban cultural practices. However, as we have explained, globalized cultural and economic models do not consider independent, undomesticated cultural alterity to be the heart of the contemporary urban structure. Street art and its situationalist aesthetics pay a special attention to the site, address, and audience opposing the spatiotemporal predisposition of art as an institutionalized practice (Foster, Recodings 100). When those institutional limits are broken, and when the public space of instrumental urban functions is occupied by illegitimate artistic and cultural expressions, the space is organized differently, becoming a multi-directional and multi-functional space, one which people transit not only to get places but also to be involved in an artistic or aesthetic experience of political alterity. As a contestation of the political rationality of a cultural economy appropriating culture and art as commodities, street art subverts 
the absorption tendencies and locates art and culture in strategic spaces in the urban structure (Rutten, Dienderen, and Soetaert 637).

The city of Puebla displays an active urban scene of informal practices many of them related exclusively to commerce but many related to art and culture as an informal economy in the streets - negotiating the limited availability of institutional spaces reserved for high culture and experimental trends (López Cuenca). The city's landscape is in this sense diverse, mixing traditional expressions, such as son trios, organ grinders, indigenous fiddlers, clowns, and fire eaters, with more contemporary global trends, such as living statues, klezmer bands, and collective crocheting. In June 2017, however, Puebla's city council approved the Programa de Artistas Urbanos (PAU) [Program for Urban Artists] to regulate all practices of art in the streets. The program was approved and published in the official government newspaper with neither any previous announcement nor any presentation of its design and objectives to the general public. No prior discussions engaged with or consulted the local sectors directly involved, such as the artists, street vendors, groups, or businesses.

The PAU, it has been argued, is for the betterment and conservation of the image of the municipality, the "revitalization" of the city center, and the professionalization of the urban arts community. Its enactment, however, was the direct absorption of a wide variety of cultural practices under the common sign of a marketable urban space. It requires that artists audition to demonstrate their quality, vision, creativity, and values in order to be registered (that is, allowed) to perform in the streets. It is not clearly stated, however, by whom or under which criteria these auditions are to be held. The PAU also states that registered artists will be assigned to only thirteen pre-selected locations in the downtown area, as it is no longer permitted to perform outside these designated public spaces. Finally, artists must pay a registration fee.

Since the approval and publication of the program, many protests and civil forums have been organized to discuss its faults and ask for its repeal. This 
includes three applications for injunction. The program, however, is still in place, and some artists have submitted to its regulations in fear of losing their livelihood. Under these circumstances, art in the streets is now integrated into a municipal cultural program to strengthen local identity. It is troubling, however, that the program emphasizes that artists may not be approved or may be written off if they defy program regulations, which can include using offensive language or not showing commitment and respect, all very vague and ambiguous rules that are to be interpreted on a case-by-case basis by municipal authorities or law enforcement.

Particularly interesting is the tenth clause of the official dictum:

That, given the current economic and technological changes, which open up vast prospects for creation and innovation, particular attention should be paid to the diversity of creative offerings, to the fair recognition of the rights of authors and artists, as well as to the specific character of cultural goods and services that, as bearers of identity, of values and meaning, should not be considered merchandise or consumer goods like any other; thus, conditions must be created that are favourable to the production and dissemination of diversified cultural goods and services, thanks to cultural industries that have the means to develop themselves at local and global levels, in accordance with articles 8 and 9 of the UNESCO Universal Declaration on Cultural Diversity. ${ }^{2}$

This consideration supports the notion that cultural goods are not like other consumer goods because of their symbolic value; therefore, appropriate conditions must be generated for their production. Globalization's momentum, especially the sort advanced by international organizations like UNESCO, relies on cultural

\footnotetext{
${ }^{2}$ Our translation; the original Spanish reads: "Que, ante los cambios económicos y tecnológicos actuales, que abren vastas perspectivas para la creación y la innovación, se debe prestar particular atención a la diversidad de la oferta creativa, al justo reconocimiento de los derechos de los autores y de los artistas, así como al carácter específico de los bienes y servicios culturales que, por ser portadores de identidad, de valores y sentido, no deben ser considerados mercancías o bienes de consumo como los demás; por lo que se deben crear condiciones propicias para la producción y difusión de bienes y servicios culturales diversificados, gracias a industrias culturales que dispongan de medios para desarrollarse en los planos local y mundial, de acuerdo a lo dispuesto por los artículos 8 y 9 de la Declaración Universal de la UNESCO sobre la Diversidad Cultural" (Gobierno 3).
} 
industries for this purpose. What we find here is that, in spite of the rhetorical acknowledgement that culture is diverse and should be available to all as a human right, the State primarily considers it a good or service that is to be managed as an industry, a far cry from the field of human practices and knowledge that produce and express the relationships that constitute the social.

Art in the streets repels passive spectatorship and calls for active participation; it invokes a sense of place in which the urban territory is under continuous and dynamic processes that make visible dissimilar aspects of the social collective. Street artists construct spaces in which to express themselves and their self-actualization in the local-global spectrum of urban life. The most important part of this self-actualization is the location of people in the centre of an urban culture, creating a human climate that fosters diversity. The construction of collective urban space must not be the result of top-down policy, but of organic, grassroots organization, for which public policies should provide favourable conditions (Florida 147-53). In the practice of street art, the artist is a negotiator of signs and meanings rather than a producer of objects or a provider of services, and the regular public is an active reader rather than a passive consumer of aestheticized commodities. Here, art in the streets is a social practice engaged with opposite signs of systems of value that are everyday negotiated in the urban construction of place. What we need to emphasize is the vital importance of connecting the relegated and the disqualified, not domesticating them via absorption into the economic functions of the city.

Art in the streets is part of the urban assemblage of actors, practices, and material conditions that make a city by negotiating its institutionalized structure. This art is one of many ethnographic texts articulating the human movements and performativities of the urban space in the local-global spectrum. It, too, functions as a practice used not to impart some aesthetic value but, rather, to problematize hegemonic views of life in the city. The presence of art in the streets allows marginal populations to make visible their existence and their values in the midst 
of the global economic imaginary, offering a focal point for reflection on the condition of urban existence (Armstrong 5).

\section{Conclusion}

The result of globalization's increasingly inequitable distribution of wealth and power is imprinted in our urban places. Under these conditions, the ideals of urban identity, citizenship, cultural belonging, and inclusive urban politics are entwined with the global neoliberal approach to social development. Urban restructuring and the promotion of romanticized images of urban life tend to have a negative socio-political impact first and foremost on the underprivileged and marginalized (Harvey, Rebel 15-16). Vulnerable and marginalized populations are increasingly ensnared within global capital circulation and accumulation, especially when the right to the city is constituted by a small political and economic elite that shapes cities more and more in accordance with its own particular needs and desires (Harvey, Rebel 20, 24).

The institutionalization of art, a strategically located node in the urban structure that functions as a political instrument of power, has only become more common (Bennett 99-100). In the case of Puebla, this trend has come to include art in the streets. The public policy management of culture and street art means that the State sanctions what is socially important and what is historically acceptable, a responsibility that can be undertaken - as in Puebla - with a forceful, non-negotiable, top-down approach. Street art's subversive influence on the urban imagination resists the organizational understanding of disciplined urban image and behaviour.

As Chantal Mouffe has stated, the role of art in public space is to radicalize democratic society and make visible its inherent power struggles; this antagonism is an essential part of the social imagination, and consensus would thus always be an artificial goal, since fluidity and variability are characteristic of the social sphere ("Artistic Activism"). Performativities in public spaces are therefore always challenging political dominance, making visible what the dominant consensus 
hides for its own exigencies. A policy approach to the public space that challenges unified, domesticated practices and representations is necessarily a policy of "agonism." In this approach, which Mouffe discusses in "For an Agonistic Public Sphere," emphasis is placed on the participation and diversity of everyday life, not the domestication and contemplation of the Other (5). Identity, meaning, and the values of place are then "constituted in a process of communication and interactivity" (Drosterij) and not adopted from international organizations. The domestication of art in the streets signals an institutional vacuum filled by economic forces, and such cases are evidences of the struggle of political and cultural institutions to grasp the urban assemblages that constitute the city. This struggle produces a shattered city of accented social marginality by progressively suppressing the conditions for alterity. This cracking of the agonistic nature of social relations is to be of significant concern for those interested in sustainable social and cultural urban policies, municipal institutions, and, most of all, urban citizens themselves.

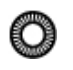

\section{Works Cited}

Armstrong, Justin. "The Contested Gallery: Street Art, Ethnography and the Search for Urban Understandings." AmeriQuests: Narrative, Law and Society, vol. 2, no. 1, 2005, pp. 1-18.

Bennett, Tony. The Birth of the Museum: History, Theory, Politics. Routledge, 1995.

Burke, Kenneth. A Grammar of Motives. U of California P, 1969.

Drosterij, Gerard. "Art and Public Space." LAPS: Research Institute for Art and Public Space, 2007, http://laps-rietveld.nl/?p=826.

Florida, Richard. The Rise of the Creative Class, Revisited. Basic, 2012.

Foster, Hal. "The 'Primitive' Unconscious of Modern Art." October, vol. 34, 1985, pp. 45-70.

—. Recodings: Art, Spectacle, Cultural Politics. Bay, 1985. 
-. The Return of the Real: The Avant-Garde at the End of the Century. MIT P, 1996.

—. "Recodificaciones: Hacia una noción de lo político en el arte contemporáneo." Modos de hacer: Arte crítico, esfera pública y acción directa, edited by Paloma Blanco, Jesús Carrillo, Jordi Claramonte, and Marcelo Expósito, Universidad de Salamanca, 2001, pp. 95-126.

Gobierno Constitucional del Estado de Puebla. Periódico Oficial del Estado de Puebla, no. 19, sec. 2, 27 June 2017.

Harvey, David. Rebel Cities: From the Right to the City to the Urban Revolution. Verso, 2012.

-. Spaces of Capital: Towards a Critical Geography. Routledge, 2001.

Hughes, Robert. The Shock of the New: Art and the Century of Changes. Thames and Hudson, 1991.

Kurjenoja, Anne Kristiina, and Emilia Ismael. "Ciudad como imagen: Xanenetla, Puebla, México, la 'Ciudad Mural.'" Revista Internacional de Ciencias Humanas, vol. 4, no. 2, 2015, pp. 263-80.

López Cuenca, Alberto. "La cultura edificante en Puebla: Arte y tragedia urbana, 2011-2017." Mundo Nuestro, 17 July 2017, http://mundonuestro.mx/index.php/ secciones/cultura/item/985-la-cultura-edificante-en-puebla-arte-ytragedia-urbana-2011-2017.

Mouffe, Chantal. "Artistic Activism and Agonistic Spaces". Art and Research: A Journal of Ideas, Contexts and Methods, vol. 1, no. 2, 2007, http:// www.artandresearch.org.uk/v1n2/mouffe.html.

—. "For an Agonistic Public Sphere." Democracy Unrealized: Documenta 11, Platform 1, edited by Okwui Enwesor et al., Hatje Cantz, 2002, pp. 87-97.

"Plan Municipal de Desarrollo, 2011-2014." Gobierno Municipal Puebla, 4 Feb. 2014, http://www.pueblacapital.gob.mx/vi-planes-municipales-de-desarrollo/174planes-municipales-de-desarrollo/3687-2011-2014-planes-municipales-dedesarrollo. 
Rutten, Kris, An van Diederen, and Ronald Soetaert. "The Rhetorical Turn in Contemporary Art and Ethnography." Critical Arts, vol. 27, no. 6, 2013, 62740.

Sassen, Saskia. Cities in a World Economy. Sage, 2002.

Anne Kristiina Kurjenoja is an Associate Professor in the Department of Architecture at the Benemérita Universidad Autónoma de Puebla (BUAP). She is a member of the Research Group in Art Theories and Contemporary Media as well as a member of Globalópolis_mx at the Universidad de las Américas in Puebla, Mexico.

Emilia Ismael is an Assistant Professor in the School of Philosophy and Letters at the Benemérita Universidad Autónoma de Puebla (BUAP). She is also a Visiting Scholar in the Department of Anthropology at the University of North Carolina at Chapel Hill. 